\title{
Reconstructing medieval April-July mean temperatures in East Anglia, 1256-1431
}

\author{
Kathleen Pribyl • Richard C. Cornes • Christian Pfister
}

Received: 17 February 2011 / Accepted: 9 October 2011 /Published online: 28 October 2011

(C) Springer Science+Business Media B.V. 2011

\begin{abstract}
This paper presents the first annually resolved temperature reconstruction for England in the Middle Ages. To effect this reconstruction the starting date of the grain harvest in Norfolk has been employed as a temperature proxy. Using c. 1,000 manorial accounts from Norfolk, 616 dates indicating the onset of the grain harvest were extracted for the period 1256 to 1431 and a composite Norfolk series was constructed. These data were then converted into a temperature series by calibrating a newly constructed comparison series of grain harvest dates in Norfolk from 1768 to 1816 with the Central England Temperature series. These results were verified over the period 1818-1867. For the British Isles no other annually resolved proxy data are available and the onset of the grain harvest remains the only proxy for assessing April-July mean temperatures. In addition, this is the first time-series regarding the onset of grain harvests in medieval Europe known so far. The long-term trend in the reconstructed medieval temperature series suggests that there was a cooling in the mean April-July temperatures over the period 1256 to 1431. Average temperatures dropped from $13^{\circ} \mathrm{C}$ to $12.4^{\circ} \mathrm{C}$, which possibly indicates the onset of the Little Ice Age. The decline in values was not steady, however, and the reconstruction period contains decades of warmer spring-early summer temperatures (for example the 1320 s to the early 1330s and the 1360s) as well as colder conditions (for example the late 1330s, 1340s and the 1380s). The decline in grain-growing-season average temperatures would not
\end{abstract}

K. Pribyl $\cdot$ C. Pfister

Section for Economic, Social and Environmental History, Institute of History, University of Bern, Bern, Switzerland

K. Pribyl $\cdot$ C. Pfister

Oeschger Centre for Climate Change Research, University of Bern, Bern, Switzerland

R. C. Cornes

Climatic Research Unit, School of Environmental Sciences, University of East Anglia, Norwich, UK

Present Address:

K. Pribyl $(\bowtie)$

School of Environment and Technology, University of Brighton, Cockroft Building, Lewes Road,

Brighton BN2 4GJ, UK

e-mail: k.pribyl@brighton.ac.uk 
have been a major problem for medieval agriculture, rather the phases of very high interannual variability partly found in the medieval time-series, such as 1315-1335 and 1360-1375, would have proved disruptive.

\section{Introduction}

A wealth of administrative/institutional records from medieval times exists in England. The number of surviving manuscripts is high compared to other regions of Europe. Seigniorial agriculture is exceptionally well documented by manorial accounts, a source almost unique to the southern parts of England, and these accounts are available in abundance for the period c. 1270-1400. These records have been widely used by agrarian historians for analysing the state of and trends in English agriculture and pastoralism. The relationship between agriculture and weather is evident and so it is not surprising that these manorial accounts contain direct weather references as well as proxy information that may be used in climate reconstructions. Their value in that respect was first realised by Titow $(1960,1970)$. He as well as Brandon (1971) collected direct weather references in some of the existing series of manorial accounts. Stern (1978) and Hallam (1984) analysed the complex link between weather and agricultural output. They incorporated proxy data into their research, but without aiming at a climate reconstruction.

Hallam's (1984) analysis of the climate and harvest size in Norfolk, East Anglia, was based on the manorial accounts of Norwich Cathedral Priory. These are available between 1256 and 1431 and many recorded the date of the grain harvest. These dates were listed due to the food provision and wage costs associated with harvesting. Therefore these data can be grouped under the classification of wage payment dates (WPD) as defined by Wetter and Pfister (2011).

The start of the grain harvest is dependent upon the grain ripening, which in turn is a proxy indicator of the mean temperatures of the grain growing season. Therefore the grain harvest date has been used in several reconstructions of the growing season mean temperature based on regression analysis: for the post-1500 era (Pfister 1979; Tarand and Kuiv 1994; Nordli 2001, 2003; Kiss et al. 2011; Možný et al. 2011) and even back to c. 1450 (Brázdil and Kotyza 2000; Wetter and Pfister 2011). Documentary sources of the narrative type mainly used for climate reconstruction at the beginning stages of historical climatology tend to emphasise extreme conditions (Pfister et al. 2008; Brázdil et al. 2010). A distinction needs to be made, however, between narrative/individual sources and administrative/institutional sources. The latter were not made for the purpose of recording climate and while they also contain direct references to extreme events, they often include unbiased proxy data which can be used for reconstructions (Pfister et al. 2008; Brázdil et al. 2010). Grain harvest dates fall into the latter category.

The Norwich Cathedral Priory material combined with some supplementary smaller series has the potential to provide a temperature reconstruction for the Middle Ages. Indeed such a temperature time series has not previously been possible during this time and also in this region. Not only is no other natural proxy for summer half year temperatures available for the British Isles, but the period covered lies at the transition from the Medieval Climate Anomaly (MCA) to the Little Ice Age (LIA). Temperatures in Norfolk achieve high correlations with temperature in other parts of the British Isles (Jones and Hulme 1997) and therefore also the Benelux countries given their geographical proximity. They are therefore crucial for establishing northwest European conditions. As the density of documentary sources usually decreases back in time and with it the frequency of weather references and 
proxy data, the grain harvest date in the Norfolk manorial accounts constitutes a very early temperature proxy that may be gleaned from documentary sources. This pre-dates even the temperature reconstruction developed using the Burgundy vine harvest dates 1370 to 2003 by Chuine et al. (2004) as well as the reconstruction of Swiss spring-summer temperatures from grain harvest dates 1454-1970 by Wetter and Pfister (2011). While the Low Countries winter and summer indices start in the eighth century $\mathrm{AD}$, the data density for the winter half year is low before c. 1200 and for summer before 1300 (van Engelen et al. 2001). The Low Countries winter and summer indices are based on direct weather references and other climate related information collected by Buisman and van Engelen (1995, 1996, 1998). Additionally, for Western Europe in the Middle Ages the compilation of weather events by Alexandre (1987) is also available and weather references from medieval documentary sources of the Czech lands have been collected and analyzed by Brázdil and Kotyza (1995).

The variation in global mean temperature over the last 1000 years has been studied extensively (Jones et al. 2009), but considerable uncertainty still exists in the variability at the regional scale (Mann 2009). For improving the spatial pattern more regional temperature reconstructions are needed. The annually resolved reconstruction of growing season temperatures for Norfolk 1256-1431 based on the grain harvest date of written records is one such series that may help in this respect.

\section{Data}

\subsection{The medieval grain harvest data}

Manorial accounts are an administrative/institutional source necessitated by the direct management of the seigniorial estates (as opposed to leasing them piecemeal or to farmers) and were common in southern England between the second half of the thirteenth century to the end of the fourteenth or the beginning of the fifteenth century. A high percentage of manorial accounts in England surviving today were made for ecclesiastical estates; ecclesiastical institutions were not just long-lived and highly organized, but also had the means to safeguard their muniments in secure archives. The manorial accounts were part of a system that enabled a non-resident landlord to control and assess the economic performance of his directly managed manor. These documents report the cost and profits of the farming activities on the manor; they list expenses and receipts and consider the state of the agricultural and pastoral sectors. As a by-product they can contain proxy information such as the harvest date, which may be used to infer the climate, and also direct weather references, if the weather interfered with the agricultural production. The accounts were usually made annually for an individual manor and cover the agricultural year, which is the time from Michaelmas (29 September) to the following Michaelmas (the year of harvest). The information was supplied by the personnel managing the manor, recorded by scribes in medieval Latin on a parchment roll and was checked in an audit process by the landlord or his representatives. Consequently the direct weather references as well as the proxy data in the accounts are highly reliable: the information is verified and contemporary, and depending on the survival rate of the parchments it is often continuous and can produce long time-series.

The date of the beginning of the grain harvest is recorded in the manorial accounts of several major landowners in Norfolk in the late Middle Ages. The longest and most complete series of accounts comes from Norwich Cathedral Priory, for which 840 accounts survive for the period 1256-1431. Additionally shorter series have been included. They come from the manors of the Bishop of Norwich, the abbey St Benet's of Hulme and 
St Giles's Hospital in Norwich as well as from the manors Hunstanton, Heacham and Ringstead. In total the number of manorial accounts used amounts to c. 1,000. ${ }^{1}$ Almost all of the 45 villages that supply harvest dates are situated in Norfolk, the only exceptions, Denham and Henley, are in central Suffolk, see Fig. 1 and Table 1.

Norwich Cathedral Priory turned to the direct management of its estates around 1250 (Virgoe 1996) with the first accounts surviving for 1255-1256. Between 1290 and 1328 a high number of accounts are available per year. The 1330s and 1340s are less well covered. The Great Plague 1348-1349 (e.g. Hatcher 1977) changed the socio-economic fundament of the direct estate management. As a result, accounts for a lower number of manors survive, but whereas gap years were frequent before 1350, the information - apart from the 1380 s - became more continuous afterwards. Although the conditions for the direct management of the manors deteriorated for economic reasons in the late fourteenth century, Norwich Cathedral Priory persisted in this practice. The last manorial accounts are available for the early 1430s and come from the large manors of Sedgeford and Gnatingdon in the northwest of Norfolk. These two manors were leased out to farmers in the mid-1430s and administrative documents drawn-up after that time merely record rents, but neither direct nor indirect weather references.

Despite providing a good and long run of account rolls and forming the backbone of the harvest date study, gap years remain in the Norwich Cathedral Priory series. For reducing the number of missing values and for verifying the Norwich Cathedral Priory data independent minor series of manorial accounts from the estates of St Benet's of Hulme, St Giles's Hospital and the Bishop of Norwich as well as from the manors Hunstanton, Heacham and Ringstead are also used.

Most of the Norfolk manorial accounts mention harvest date and length. This information is usually supplied at various points in the manorial accounts, as it is the case in the Norwich Cathedral Priory rolls: until 1390 in the paragraph on the harvest itself, until 1328 in the paragraph on the dairy production and after 1355 in the paragraph on harvest works. Thus over long periods of time, cross-checking the harvest date is possible and this improves the reliability of the data. The reason for this frequent mentioning of the harvest date and length in the accounts is the cost of harvesting. Many harvest workers were entitled to eat at the "lord's table" during harvest time, which means they were provided with food and drink (including dairy products) by the manor, and they often also received wages.

The harvest date refers to the cutting of the winter crops, wheat and rye. Wheat was usually ripe some days before the rye (Ernle 1961). Later in the harvest season the attention would have turned to barley, the main crop in Norfolk, as well as oats. At the end, the harvesters dealt with the legumes, if they had not been fed green to the manorial animals/ livestock.

\footnotetext{
${ }^{1}$ The manorial accounts of Norwich Cathedral Priory are in the Norfolk Record Office (NRO) under DCN 60/02, 04, 07, 08, 10, 13, 14-6, 18, 20, 23, 25-6, 28-30, 33, 35, 37, 39, DCN 61/6-12, 14-26, 30-1, 33-4, 39-42, 45-8, DCN 62/1-2, MC 212/1-14, LEST/IB 15-70, LEST/IC 1-53 and NRS 5889, 20 D1-5923, 20 D3 and in the Bodleian Library, Oxford under MS Rolls Norfolk. The remnants of the medieval episcopal archive are under NRO DCN 95/4-7, 9-11, 13-4, 20. The records of St Benet's of Hulme NRO DN/EST 1/ 3-22, DN/EST 9/1-20, DN/EST 10/1-5, DN/EST 11/2-11. The muniments of St Giles's Hospital are in the NRO in the Records of the City of Norwich (NCR) Press G, Case 24 Great Hospital. The rolls of the following manors of this collection were used: Shelf c: Calthorpe 1315-1460 (many missing) and Costessy 1338-1460 (many missing), Shelf d: Cringleford 1295-1442 (many missing), Shelf e: Hardley 1331-1460 (many missing), Shelf i: South Walsham 1399-1461 (many missing). The manorial accounts of Heacham are in NRO LEST/DG 1-6, those of Hunstanton under NRO LEST/BG 1-18 and Ringstead under NRO LEST/ EG 1-12.
} 


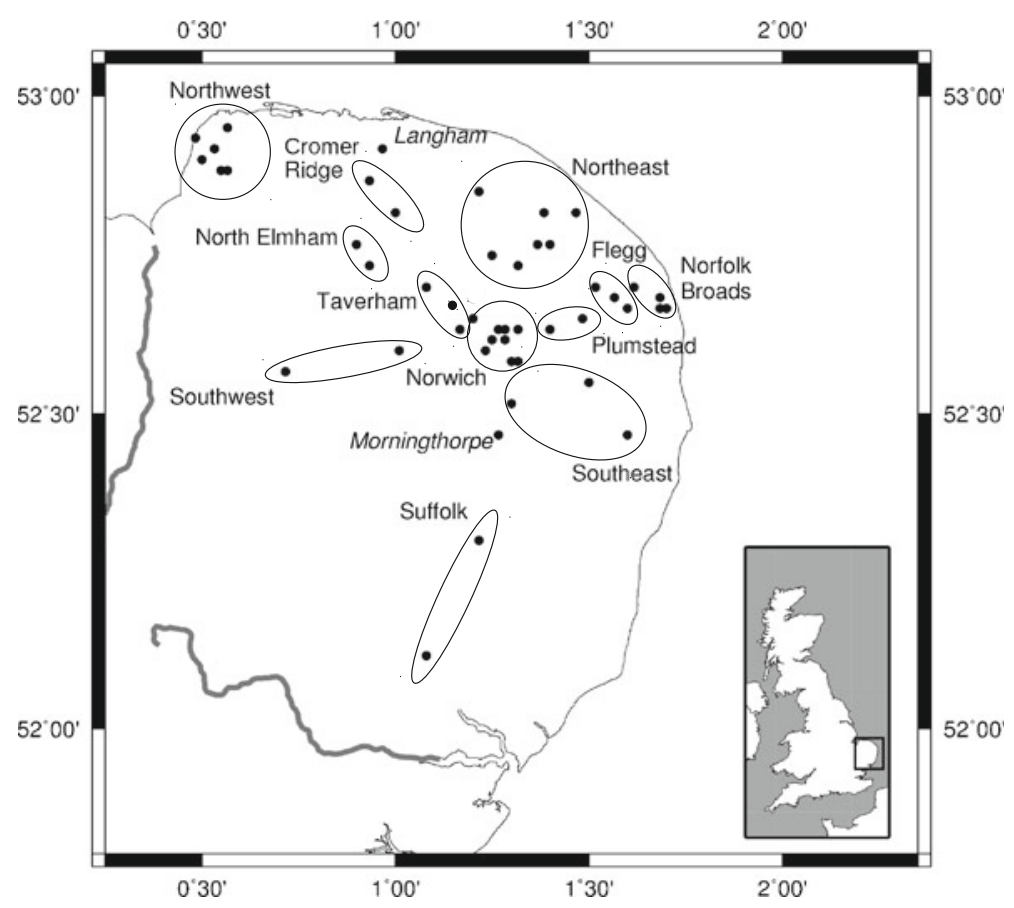

Fig. 1 A map of East Anglia showing the manors providing grain harvest date information. Also shown are the locations of the two farms (Langham and Morningthorpe) that provide harvest dates for the eighteenth century comparison series

Since the strips making up the land directly managed by the manor and the strips leased to the tenants lay intermingled in the open fields, the harvest date for the manor equals the harvest date for the village. When harvest time was approaching senior villagers and manorial managers set the harvest date, according to the development stage of the grain (see the discussion in Pfister 1979 regarding a similar situation in eighteenth century Switzerland). The time window for successful harvesting was short, 8 to 10 days in a dry season. If the harvest started too early, the grain would lack nutrition, if the harvest started too late, the grain would be over-ripe. Over-ripeness resulted in the kernels being loose in the ear and falling to the ground when the corn was harvested, thus greatly increasing waste (Collins 1969). Shattering and shedding were common problems until the mechanisation of the harvest process.

The harvest date had to be consciously set by the village community and the manorial staff. Since it involved mobilising a large labour force, certain traditions came into play when setting the harvest date. Often that day would be at the beginning or less commonly towards the middle of the week or close to a saint's or feast day. Since a week has just 7 days and important ecclesiastical feast days were 25 July, 1 August, 10 August, 15 August and 24 August, this dating system is sufficiently flexible to operate within the framework set by the phenological state of the grain. The system is more rigid at the beginning of the reconstruction period and softens over time: divergence from the system was always possible (Pribyl 2011). The official start of the harvest season in medieval England was 1 August, St Peter in Chains, and this day figures frequently in the harvest dates until c. 1290. 
Table 1 Manors used in this study, allocated to groups based on geographical proximity

\begin{tabular}{|c|c|c|c|c|c|}
\hline Region & Latitude & Longitude & Region & Latitude & Longitude \\
\hline Northwest & & & Taverham & & \\
\hline Sedgeford & $52^{\circ} 53^{\prime}$ & $0^{\circ} 33^{\prime}$ & Attlebridge & $52^{\circ} 42^{\prime}$ & $1^{\circ} 08^{\prime}$ \\
\hline Gnatingdon & $52^{\circ} 53^{\prime}$ & $0^{\circ} 34^{\prime}$ & Bawburgh & $52^{\circ} 38^{\prime}$ & $1^{\circ} 10^{\prime}$ \\
\hline Thornham & $52^{\circ} 57^{\prime}$ & $0^{\circ} 34^{\prime}$ & Taverham & $52^{\circ} 41^{\prime}$ & $1^{\circ} 12^{\prime}$ \\
\hline Hunstanton & $52^{\circ} 56^{\prime}$ & $0^{\circ} 29^{\prime}$ & & & \\
\hline Ringstead & $52^{\circ} 55^{\prime}$ & $0^{\circ} 32^{\prime}$ & Plumstead & & \\
\hline \multirow[t]{2}{*}{ Heacham } & $52^{\circ} 54^{\prime}$ & $0^{\circ} 30^{\prime}$ & Plumstead & $52^{\circ} 38^{\prime}$ & $1^{\circ} 24^{\prime}$ \\
\hline & & & South Walsham & $52^{\circ} 39^{\prime}$ & $1^{\circ} 29^{\prime}$ \\
\hline \multicolumn{6}{|l|}{ Cromer Ridge } \\
\hline Hindringham & $52^{\circ} 52^{\prime}$ & $0^{\circ} 56^{\prime}$ & Norwich & & \\
\hline \multirow[t]{2}{*}{ Hindolveston } & $52^{\circ} 49^{\prime}$ & $1^{\circ} 00^{\prime}$ & Arminghall & $52^{\circ} 35^{\prime}$ & $1^{\circ} 18^{\prime}$ \\
\hline & & & Catton & $52^{\circ} 38^{\prime}$ & $1^{\circ} 17^{\prime}$ \\
\hline Northeast & & & Eaton & $52^{\circ} 37$ & $1^{\circ} 15^{\prime}$ \\
\hline Worstead & $52^{\circ} 46^{\prime}$ & $1^{\circ} 24^{\prime}$ & Lakenham & $52^{\circ} 37^{\prime}$ & $1^{\circ} 17^{\prime}$ \\
\hline Witton & $52^{\circ} 49^{\prime}$ & $1^{\circ} 28^{\prime}$ & Monks' Grange & $52^{\circ} 38^{\prime}$ & $1^{\circ} 19^{\prime}$ \\
\hline Hevingham & $52^{\circ} 45^{\prime}$ & $1^{\circ} 15^{\prime}$ & Trowse Newton & $52^{\circ} 35^{\prime}$ & $1^{\circ} 19^{\prime}$ \\
\hline Little Hautbois & $52^{\circ} 44^{\prime}$ & $1^{\circ} 19^{\prime}$ & Heigham & $52^{\circ} 38^{\prime}$ & $1^{\circ} 16^{\prime}$ \\
\hline North Walsham & $52^{\circ} 49^{\prime}$ & $1^{\circ} 23^{\prime}$ & Costessy & $52^{\circ} 39^{\prime}$ & $1^{\circ} 12^{\prime}$ \\
\hline Scottow & $52^{\circ} 46^{\prime}$ & $1^{\circ} 22^{\prime}$ & Cringleford & $52^{\circ} 36^{\prime}$ & $1^{\circ} 14^{\prime}$ \\
\hline \multirow[t]{2}{*}{ Calthorpe } & $52^{\circ} 51^{\prime}$ & $1^{\circ} 13^{\prime}$ & & & \\
\hline & & & Southwest & & \\
\hline North EImham & & & Great Cressingham & $52^{\circ} 34^{\prime}$ & $0^{\circ} 43^{\prime}$ \\
\hline Gateley & $52^{\circ} 46^{\prime}$ & $0^{\circ} 54^{\prime}$ & Hardingham & $52^{\circ} 36^{\prime}$ & $1^{\circ} 01^{\prime}$ \\
\hline \multirow[t]{2}{*}{ North Elmham } & $52^{\circ} 44^{\prime}$ & $0^{\circ} 56^{\prime}$ & & & \\
\hline & & & Southeast & & \\
\hline Norfolk Broads & & & Aldeby & $52^{\circ} 28^{\prime}$ & $1^{\circ} 36^{\prime}$ \\
\hline Hemsby & $52^{\circ} 41^{\prime}$ & $1^{\circ} 41^{\prime}$ & Shotesham & $52^{\circ} 31^{\prime}$ & $1^{\circ} 18^{\prime}$ \\
\hline Martham & $52^{\circ} 42^{\prime}$ & $1^{\circ} 37^{\prime}$ & Hardley & $52^{\circ} 33^{\prime}$ & $1^{\circ} 30^{\prime}$ \\
\hline Ormesby & $52^{\circ} 40$ & $1^{\circ} 41^{\prime}$ & & & \\
\hline \multirow[t]{2}{*}{ Scratby } & $52^{\circ} 40^{\prime}$ & $1^{\circ} 42^{\prime}$ & Suffolk & & \\
\hline & & & Denham & $52^{\circ} 18^{\prime}$ & $1^{\circ} 13^{\prime}$ \\
\hline Flegg & & & Henley & $52^{\circ} 07^{\prime}$ & $1^{\circ} 08^{\prime}$ \\
\hline Ashby & $52^{\circ} 41^{\prime}$ & $1^{\circ} 34^{\prime}$ & & & \\
\hline Flegg & $52^{\circ} 40^{\prime}$ & $1^{\circ} 36^{\prime}$ & & & \\
\hline Ludham & $52^{\circ} 42^{\prime}$ & $1^{\circ} 31^{\prime}$ & & & \\
\hline
\end{tabular}

The harvest work on the land of the lord was mostly done by local labour either in the form of customary labour dues or hired labour. The lord had the priority in hiring harvesters, so an easy access to the local labour market was guaranteed for him. It was also difficult for villagers to leave their village during harvest time (Ault 1972), consequently the local labour force was employed flexibly in the harvest. After 1350 bands of wandering harvesters emerged, but they played a subordinate role compared to the locals (Ernle 1961). 


\subsection{The eighteenth-nineteenth century grain harvest data}

To effect a temperature reconstruction using the medieval data, the modern comparison series of harvest dates must also come from Norfolk. It must overlap with temperature measurements, which are available in the form of the Central England Temperature (CET) series from 1659 onwards, but it must come from a time before the mechanisation of the harvest process, i.e. before the second half of the nineteenth century. This guarantees comparable harvesting conditions. Two collections of Norfolk farming diaries fulfil these criteria and furnish grain harvest dates for the years around 1800.

The first collection comes from the farm of Stephen Frost at Langham 1768-1816. ${ }^{2}$ Langham is a village not far from the North Norfolk Coast, and is located on the soft northern slopes of the Cromer Ridge. The Langham information on the grain harvest date is almost complete, gaps occur in 1782, 1792, 1804, 1809, 1814 and 1817, so that in total 44 years are covered. Indeed the harvest date series from Langham is longer, stretching to 1867 , but a break occurs in the data after 1816. This break shifted the mean value of the harvest date and coincides with a change in ownership, though it is not clear what caused the actual break. ${ }^{3}$ At the Langham farm the crops were harvested with the help of itinerant harvest gangs, their arrival usually marked the start of the harvest. Often, however, the employees of the farm and hired labourers began to cut the wheat a few days before the arrival of the harvest gang. For capturing the signal of the harvest date, in such years the wheat harvest date was used instead of the date related to the harvest gang. Especially up to 1816 there is tendency on Langham farm to start the harvest and the cutting of corn at the beginning of the week.

The second run of modern grain harvest dates could be established for an estate at Fritton/Morningthorpe, a village about $15 \mathrm{~km}$ to the south of Norwich. ${ }^{4}$ This series is complete between 1803 and 1828 . The data from this farm were not directly used in this study because the series is too short for the use of the calibration-verification technique. However, a comparison with the Langham series (not shown) reveals the two series to be highly correlated over the $1803-1828$ period.

\section{Methods}

The temperature reconstruction was achieved using a common calibration-verification approach following the method described by Brázdil et al. (2010). With the help of the comparison series from Langham 1768-1816 the relationship between growing season temperature and grain harvest date was established, which in turn served to determine the medieval temperatures values. For that purpose medieval as well as modern harvest dates

\footnotetext{
${ }^{2}$ Stephen Frost of Langham, farming diaries 1768-1816: NRO MC 120/1-44, Thomas Rippingall, farming diaries 1817-1831, Thomas Rippingall and Rev. Stephen Frost Rippingall, farming diary 1832, Rev. Stephen Frost Rippingall, farming diaries 1833-58: NRO MC 120/45-85, William Rippingall, personal diaries 185961: NRO MC/121-3, the harvest book 1847-61/67: NRO MC 120/87.

${ }^{3}$ The shift is probably due to a variety of factors including a change in farming practices, like determining the stage of ripeness of the grain (Collins 1969), and the enclosure of the Langham open fields in 1815 (http://www.legislation.gov.uk/changes/chron-tables/private/25\#f2). In any case it can be assumed that farming at Langham 1768-1816 is not just temporally closer to the Middle Ages, but also that the general conditions of farming in this period are more related to medieval conditions than those in the later Langham series.

${ }^{4}$ Thomas Howes of Morningthorpe, farming diaries for Fritton estate 1802-27: NRO MC 150/52/1-2.
} 
were converted into year days; medieval harvest dates also had to be adjusted to the Gregorian calendar.

\subsection{Construction of the composite medieval harvest date series}

The nature of the medieval grain harvest data poses challenges to constructing a composite series of Norfolk grain harvest dates and therefore also to a quantitative statistical analysis. The c. 1,000 manorial accounts used render 616 useable harvest dates, but they are not equally distributed over time (see Fig. 2). All series from individual manors contain missing values between 1256 and 1431 and some series are very short indeed. Due to climatic factors, soil, elevation or exposure to wind the mean values of the various series of harvest dates also differ: there are regions where harvests started generally earlier than elsewhere and vice versa. To overcome these problems and to construct a composite series out of the 616 medieval grain harvest dates for Norfolk, the data were grouped. This initial step is crucial and was taken on the basis of geographical proximity and the relationship between the various series. Twelve regions could be identified (Fig. 1 and Table 1).

Regional harvest date series were created by using the earliest beginning of the harvest in any given year in each group. Alternative regional harvest date series were also constructed by taking the mean value of the available dates per year and group. However, differences between these two series are minor, because often several manors of one region report identical or nearly identical harvest dates or data simply do not overlap. The differences are restricted to the regional groups rich in data, such as Norwich, Northwest or Cromer Ridge. Since it is also problematic to calculate average regional values due to the variations in the number of available data per year, further analysis is based on the regional harvest date series using the minimum value from each group.

For constructing a composite Norfolk harvest date series all twelve regions were regressed to the level of the region Northwest, which holds the longest and most continuous series of harvest dates. The group also lies only about $25 \mathrm{~km}$ to the west of Langham, the home of the modern comparison series. Both of these locations are in close proximity to the north Norfolk coast and are situated on largely similar, well draining soils (Soil Survey of England and Wales 1983). For completing missing values in the Northwest series, regressed data from the other regions were selected in a hierarchical manner based on the $\mathrm{r}^{2}$ values of the various regions in relation to the Northwest group. This composite series covers

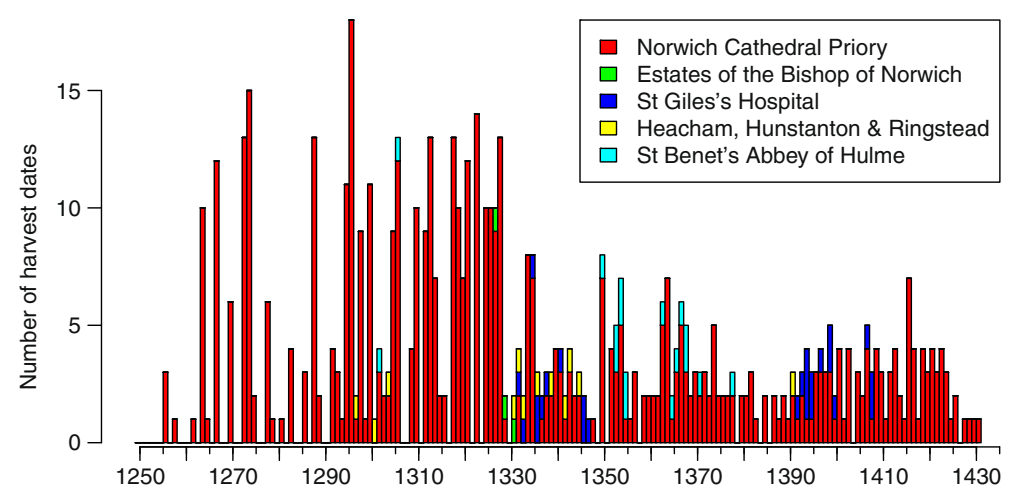

Fig. 2 The numbers of Norfolk harvest dates per year used in this study 
143 years between 1256 and 1431, data density is high after 1290 (Fig. 2). An alternative composite series was assembled by simply taking the mean value of the available harvest dates from the twelve regions. The apparent low-frequency and long-term trend are not affected by the different ways of constructing the composite series, but the interannual variability is suppressed in the series made of the mean values from the twelve regional groups. Consequently due to its proximity to Langham, the soil and microclimatic conditions shared with that village and its ability to capture the natural variance, the composite series based on the Northwest group, and the harvest dates regressed towards its level, is better apt for a temperature reconstruction.

\subsection{The harvest date-temperature relationship}

The relationship between grain harvest date and temperature was established by using the monthly Central England Temperature series (CET) (Manley 1953, 1974) and the Langham harvest date series 1768-1816 $(n=44)$. The highest correlation was achieved for April-July mean temperatures with $62 \%$ of the variance of harvest dates explained by the temperature at Langham ( $r=-0.79$, Fig. 3). It should be noted, however, that March and August temperatures are also influential, and when including March and/or August into the period of mean temperatures the correlations remain close to the coefficient for April-July. The strong linear relationship that is evident between grain harvest date and temperature coincide with the period of the year that can be identified as the grain growing season. We suspect that a significant proportion of the unexplained variance is due to rainfall and partly also to the time of sowing. The Durbin-Watson statistic of 1.4 for this model indicates no significant autocorrelation in the residuals.

A clear break is evident in the Langham harvest series in 1818 (Fig. 4). The mean of the series over the period 1818-1867 is $\sim 8$ days lower than for the period 1768-1816 (Table 2). Using Student's $t$-test the difference in means between the two periods is significant at $p<0.01$. The exact cause of this break is unknown, although a change in farm ownership coinciding with a change in farming practices (as described above in Section 2.2) is the most likely reason. Importantly, the overall mean of the medieval Norfolk composite group (1256-1431) is comparable to the early Langham series (1768-1816). An implication of

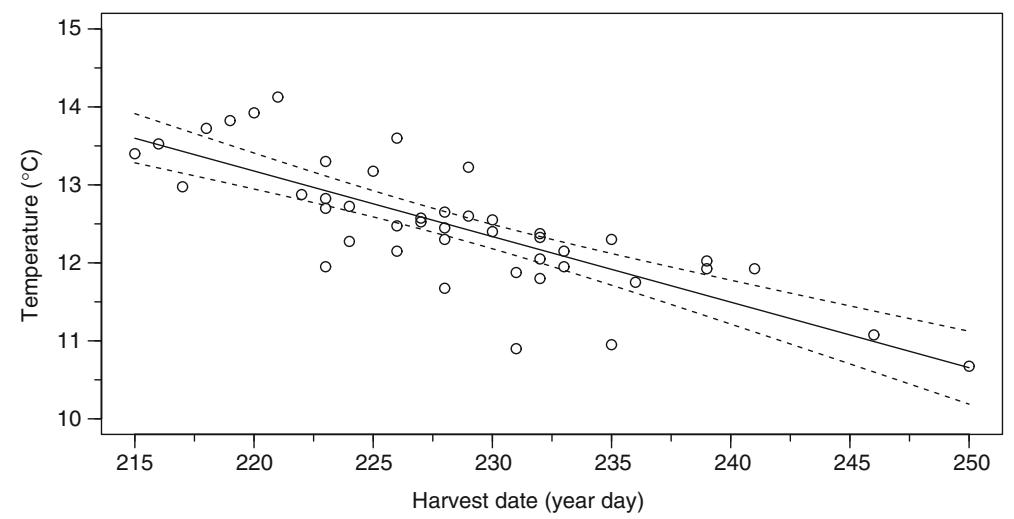

Fig. 3 A scatterplot showing the relationship between grain harvest date at Langham (1768-1816) and mean April-July temperature derived from the CET series. Also shown are the linear regression line and the $95 \%$ confidence interval 


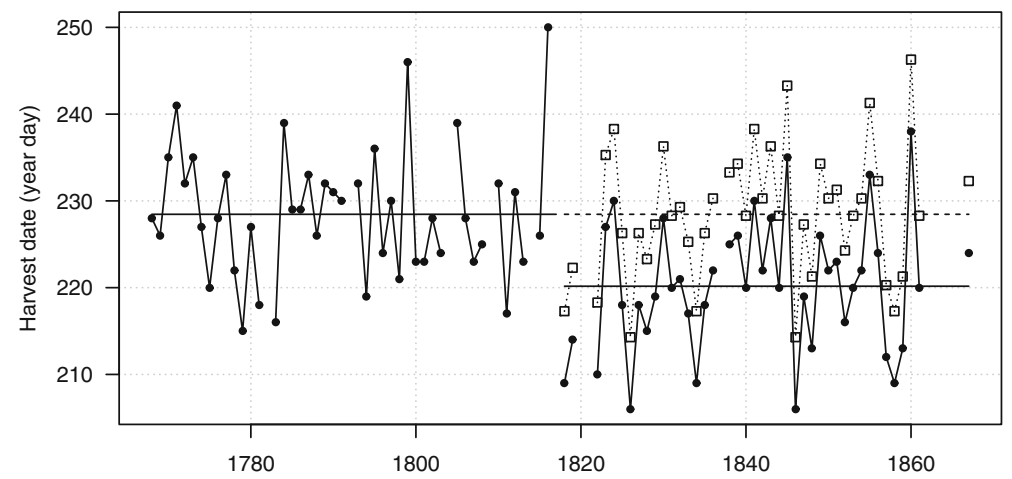

Fig. 4 The Langham harvest date series (1768-1867). The dotted line indicates the series (1818-1867) adjusted so that the mean equals that of the earlier (1768-1816) period. The horizontal lines indicate the means for the respective periods

this is that the relationship established for Langham grain harvest dates and the April-July mean temperatures is most likely also relevant for the medieval Norfolk composite group.

Using linear regression, a transfer function was established between the harvest date (predictor) and the mean April-July temperature (predictand) over the 1768-1816 period. Despite the break in the Langham series, the later data (1818-1867) can be used for verification purposes, given that the change only appears to affect the series' mean. However, to allow comparison with the data from the calibration period, the verification data needed to be homogenized to the earlier period through the addition of 8 days to each value. This homogenization approach is akin to methods that are routinely used when homogenizing meteorological observations (e.g. Aguilar et al. 2003). The correlation coefficient of the reconstructed temperatures against the recorded temperatures for the 1818-1867 period is unaffected by this homogenization procedure because only the mean of the series has been shifted, and is significantly positive $\left(r=0.84, r^{2}=0.71, n=42, p<0.01\right)$. Conversely, the Reduction of Error (RE) and Coefficient of Efficiency (CE) statistics (see Cook et al. 1994 and Kiss et al. 2011) are greatly affected by the homogenization of the data. Prior to applying the 8-day correction the RE and CE values stood at -0.51 , indicating that the reconstruction is worse than using the climatological mean value. This occurs because the mean recorded April-July temperatures for the 1768-1816 and 1818-1867 periods are very similar $\left(12.5^{\circ} \mathrm{C}\right.$ and $12.4^{\circ} \mathrm{C}$ respectively), while the harvest date series suffers from an

Table 2 Statistical characteristics of the grain harvest dates of the medieval Norfolk composite series and the eighteenth to nineteenth century comparison series from Langham (year days and dates in Gregorian Calendar). 'SD' stands for standard deviation, and ' $\mathrm{n}$ ' for the number of values

\begin{tabular}{llll}
\hline & Norfolk composite series 1256-1431 & Langham 1768-1816 & Langham 1818-1867 \\
\hline Mean & 226.7 (15 Aug.) & 228.5 (17 Aug.) & 220.2 (8 Aug.) \\
SD & 7.1 & 7.5 & 7.6 \\
Earliest & 204 (23 Jul.) & 215 (3 Aug.) & 206 (25 Jul.) \\
Latest & 247 (4 Sep.) & 250 (7 Sep.) & 238 (26 Aug.) \\
$n$ & 143 & 44 & 42 \\
\hline
\end{tabular}


artificial, human-induced shift. Applying the RE and CE tests to the homogenized data produces values of 0.69 for both tests, which indicates skill in the reconstruction. Briffa et al. (1988) highlighted the inaccurate test results that may be achieved in calibration-verification exercises when differences are apparent in the mean recorded temperatures between the calibration and verification periods; they advocated the stricter $\mathrm{CE}$ test for this reason. The results here indicate a further consideration when undertaking calibration-verification exercises, in that the RE and $\mathrm{CE}$ tests may wrongly indicate that the reconstruction is unskilful because of inhomogeneities in the calibration-verification data.

\subsection{The medieval temperature reconstruction}

Using the regression equation obtained from the eighteenth century Langham comparison series, the medieval temperature series was constructed by substituting medieval harvest dates as the predictor. This regression transfer technique has several limitations that must be addressed. Although the similarity in the statistical properties of the harvest date series of the medieval Norfolk composite series and Langham are clear, inhomogeneities in the data might have been caused by a number of factors, as has been pointed out by Nordli (2001) for nineteenth-century Norwegian farms. The influence of corn crop breeding between the Middle Ages and the late eighteenth century is most likely negligible for the grain harvest date, because the farmers aimed at having more resistant and reliable, but not early-ripening crops. Although for the Middle Ages the information about which crop was cut first in the grain harvest is not explicitly given in the sources, it must have been the winter crops and of those rather wheat than rye, because rye ripens slightly later than wheat (Ernle 1961). The composition of the corn crops on the fields of Norfolk changed in the fourteenth century. Before 1350 rye was common, but was then increasingly marginalized in the decades following the Black Death, the acreages sown with wheat on the other hand remained stable c. 1250-1449 (Campbell and Overton 1993). Merely three manors in the Norwich group and Taverham do grow rye but no wheat for some runs of years or single years until the 1330s. This does not affect their harvest date in relation to the other manors, the grain harvests of those three manors generally have a low mean value compared to other manors. Considering this and the fact that in medieval England and also in Norfolk the growing of maslin, a mixture of rye and wheat, was practised (Campbell 2000), the mean values in the harvest dates of these two winter crops are evidently very close. Stephen Frost at Langham 1768-1816 and 1818-67 does not refer in his farming diaries to sowing or harvesting rye at all, but he grew wheat in all years. Hence the harvest dates from Langham always refer to the wheat harvest. Therefore the medieval and the eighteenth century data refer to the same phenological state.

A potential problem is also posed by the harvesting method. Before mechanisation there were two ways to harvest the corn crops: reaping and mowing. The cheaper and quicker mowing was introduced in Norfolk after 1350 and gained importance over the following decades (Stone 2005), more than half of the crops were mown in the Northwest region after 1390 (Pribyl 2011). Causing greater waste, the mowing of corn was usually restricted to the cheaper spring crops, barley and oats. This was still the situation in eighteenth century Norfolk (Wade Martins and Williamson 1999), and at the Langham farm mowing was probably extended to wheat between 1833 and $1838 . .^{5}$ Interestingly, this extension to mowing of wheat, which is harvested before the spring crops, does not cause a break in the

\footnotetext{
${ }_{5}^{5}$ The Langham farming diaries for those years are under NRO MC 120/61-5.
} 
Langham harvest date series. The measured CET April-July mean temperatures 1817-1867 relate to the reconstructed temperatures in the $1830 \mathrm{~s}$ and $1840 \mathrm{~s}$ as well as in the $1820 \mathrm{~s}$. If the introduction of the mowing of wheat did not result in a disruption in the relationship of harvest date to growing season mean temperature in the nineteenth-century data, there is no reason to assume that the increased mowing of the spring grains would do so after the midfourteenth century and especially after c. 1400 .

Consequently none of these factors is of a sufficient magnitude to cause major inhomogeneities and to fatally disrupt the relationship of grain harvest date and growing season between the late Middle Ages and the years around 1800.

\section{Results and discussion}

\subsection{Reconstructed medieval April-July mean temperatures}

In Fig. 5 the medieval temperature reconstruction is plotted. The reconstructed temperatures 1256-1431 are smoothed by a 11-year Gaussian filter. The long-term trend reveals falling April-July mean temperatures. On the one hand this is exemplified by the mean temperatures exceeding $13^{\circ} \mathrm{C}$ frequently before 1335 and occasionally even $13.5^{\circ} \mathrm{C}$. Such years are rare after 1335 . On the other hand until c. 1315 very few growing seasons were colder than $12^{\circ} \mathrm{C}$. Their frequency increased in the following decades and they were common from the 1360 s onwards. Therefore mean April-July temperatures drop from about $13^{\circ} \mathrm{C}$ at the beginning of the reconstruction period to $12.4^{\circ} \mathrm{C}$ at the end. Taking into consideration this long-term trend, high April-July mean temperatures relative to their neighbouring years are experienced in the years 1267, 1297, 1298, 1318, 1326, 1333, 1361, 1365,1400 and 1409 . Very cold growing seasons mark the years of $1275,1283,1294$, $1314,1315,1319,1323,1335,1348,1364,1370,1374,1421$ and $1428 .{ }^{6}$ However, the trend of falling April-July mean temperatures between 1256 and 1431 is not steady. Local highs in temperature are visible c. 1300-1310, 1326-1334, in the 1350s, the 1390s and the late 1410s. Temperatures were low compared to the neighbouring years in the mid-1290s, c. 1313-1323, the 1340s, the mid-1360s to the mid-1370s and 1380s. Cold years also cluster in the first decade of the fifteenth century and the early $1420 \mathrm{~s}$.

Over time, changes in the interannual variability can also be observed. Until 1290 the interannual variability was low, with most growing seasons reaching temperatures between $13^{\circ} \mathrm{C}$ and $13.5^{\circ} \mathrm{C}$. However, data density is low until 1290 and the number of consecutive years with data is limited, so that a definite assessment of interannual variability before 1290 cannot be made. Other periods of low interannual variability are located in the second half of the $1330 \mathrm{~s}$ and in the $1340 \mathrm{~s}$, in most of the $1350 \mathrm{~s}$, in the late $1370 \mathrm{~s}$ and early $1380 \mathrm{~s}$, as well as in the 1390-1398, excepting 1395, and in the 1410s. Medium ranges of interannual variability of shifts up to $1{ }^{\circ} \mathrm{C}$ mark the years c. $1290-1315$, c. $1405-1411$ and the early 1420 s. Remarkably high levels of interannual variability can be detected $1315-$ 1335 and 1360-1375; the year 1428 disturbs the otherwise calm pattern of the second half of the 1420 s and the early 1430 s greatly. During these periods jumps in growing season temperatures from one year to the next of $1.5^{\circ} \mathrm{C}$ or more are not uncommon. Evidently the grain harvest date captures the interannual frequency in the growing season temperatures

\footnotetext{
${ }^{6}$ For a more in-depth analysis on the individual years with respect to meteorological conditions as well as impacts on agriculture and society, see Pribyl (2011).
} 


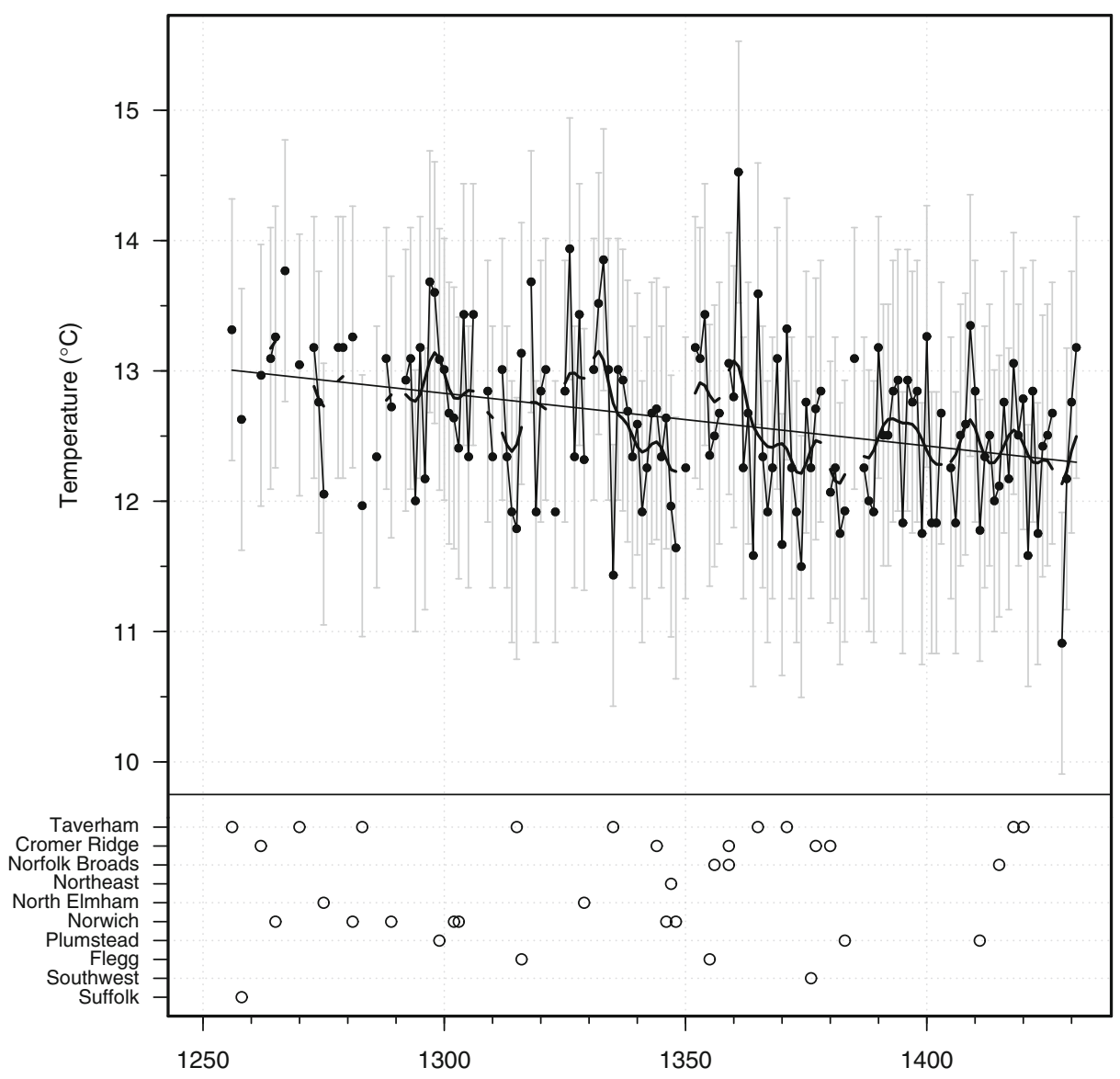

Fig. 5 The reconstructed Norfolk temperature series 1256-1431. The grey error bars represent $+/-2$ S.E. (standard error) derived from the regression analysis during the 1768-1816 calibration period. Also shown are the linear trend line and the 11-year Gaussian filtered values of the reconstructed values. The empty circles represent the values incorporated from the ten regional groups (regressed to the Northwest group) for years in which no data from the Northwest group are available

very well. This is linked on the one side to the grain crops being annual plants, whose speed in growing is not influenced by previous years, as trees might be. On the other side the nature of the non-mechanised grain harvest simply does not tolerate divergence from harvesting when the crops are ripe, as has been explained above (Section 2.1).

In Fig. 6 the reconstructed medieval temperature series is compared with the time series of mean April-July temperatures in the CET series (1659-2010). In general terms the results in Fig. 6 show the expected feature of mild conditions during the MCA period, and the decline to cooler conditions in the mid-fifteenth century probably in association with the beginnings of the LIA. These results also indicate, however, that the rate of interannual variability throughout the medieval period was similar to conditions during the 1659-2010 period. In addition, within the generally cooler $1350-1431$ period the extremely warm spring-summer of 1361 is clearly marked as an outlier $\left(14.5 \pm 1.0^{\circ} \mathrm{C}\right)$. While that value would appear exceptional in the context of 350 years of instrumental data (after 1659), and 
is generally regarded as being a hot season, ${ }^{7}$ the harvest date extends beyond the range over which the linear regression relationship was established; this renders definite conclusions about the severity of temperature during that year as somewhat problematic.

4.2 The relationship of reconstructed April-July mean temperatures to other documentary evidence

Since there are not yet any natural temperature proxies for the British Isles for the months c. April-July prior to the medieval period available, the Norfolk temperature reconstruction will be compared with the existing temperature indices made from documentary weather references by Ogilvie and Farmer (1997) for England 1200-1432 as well as the van Engelen et al. (2001) reconstruction for the Low Countries 751-2000. All these indices were created using documentary evidence independent from the Norfolk manorial accounts.

Ogilvie and Farmer (1997) reworked Lamb's (1977) indices and only used the data after submitting them to the process of source criticism. This increased the reliability of their precipitation and temperature indices resolved on the monthly level. The indices range from -3 (for temperature: extremely cold, for precipitation: extremely dry) to 3 (extremely warm, respectively extremely wet). However, there are many gaps in the England data and since it is not clear if gaps represent normal conditions which were usually not recorded in medieval narrative sources, or if they are due to missing information, this causes problems to create supra-monthly or seasonal indices. Lamb's index was largely based on the compilation produced by Britton (1937), which is a comprehensive and thorough work, but frequently overlooked reliable weather references in chronicles. Ogilvie and Farmer (1997) extended the core of weather references assembled by Britton (1937) with information using administrative/institutional sources (not from Norfolk), but do not appear to have scrutinized the chronicles for weather data overlooked by Britton, so these references are still missing in the indices. The available information for temperature is in fact so scarce that no useful correlations or comparisons can be based upon it for spring and summer, for example between 1256 and 1431 there are merely twenty nine indices for March, eight for April, five for May, nine for each June and July and seven for August.

One has to turn to the Low Countries and the work by van Engelen et al. (2001) for finding a more complete temperature index based on documentary sources for the summer season (May-September) and indeed for the winter season (November-March). Their summer series covers 158 years between 1256 and 1431 and ranges from 1 (extremely cool) to 9 (extremely warm). The Low Countries data are sufficiently close to Norfolk for a comparison to be valid. Although the summer season index for the Low Countries does not cover exactly the months April-July, the Spearman rank correlation between the reconstructed Norfolk temperatures and the Low Countries temperatures based on the summer half year index stands at $\rho=0.46$. Figure 7a shows the reconstructed Norfolk temperatures and the Low Countries index, both expressed in z-scores. Summers which are considerably warm in the reconstructed Norfolk

\footnotetext{
${ }_{7}$ The summer of 1361 figures as 8 in the index (index scale ranging from 1'extremely cool' to 9 'extremely warm' for summer temperature) for the Low Countries by van Engelen et al. (2001). A wide array of references to drought and partly also to heat for large parts of continental Europe is given by Alexandre (1987). In England John of Reading refers in his Chronica to a major drought and describes heat impacts (Tait 1914), the manorial accounts of the estates of the Bishopric of Winchester give information on a severe drought and refer literally to "great heat" (Titow 1970). A direct reference to the high temperatures is unusual in these times and underlines the severity of the conditions. Normally early documentary sources focus on hydro-meteorological extremes, because of their greater impact upon agriculture and the wider economy (Pfister et al. 2008).
} 


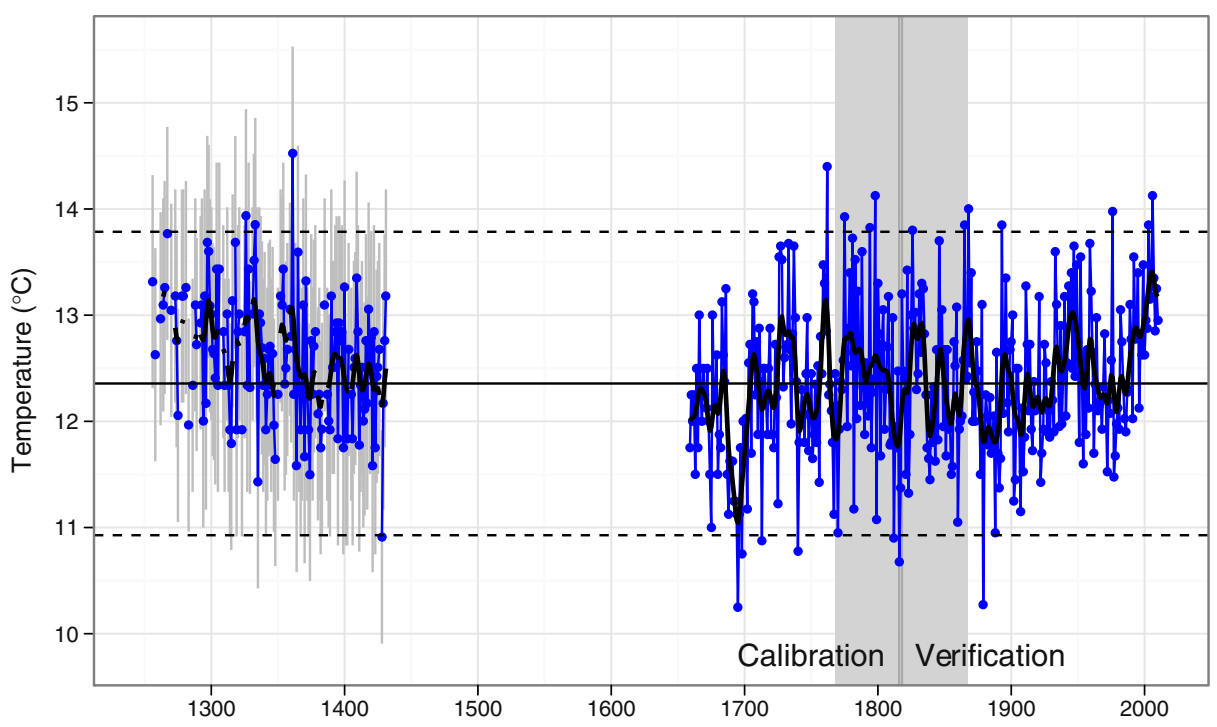

Fig. 6 A comparison of the reconstructed and instrumental (CET) April-July mean temperature series. The error bars represent \pm 2 S.E. (standard error) from the calibration-period regression analysis (1768-1816) and the thick lines show the 11-point Gaussian filtered values. Also shown are the mean (horizontal line) and the \pm 2 standard deviations (horizontal dashed lines) of the instrumental data (1659-2010). The periods used for calibration (1768-1816) and verification (1817-1867) are indicated in the shaded areas

growing season temperatures and the Low Countries summer season index are 1267, 1297, $1318,1326,1332,1333,1361$ and 1400; the values for 1275, 1283, 1294, 1314, 1315, 1335 , 1406, 1411 and 1428 appear as very cold in both datasets.

By comparing the Low Countries index to the reconstructed Norfolk temperature an important feature becomes apparent. Before 1350 several summers that are classified as very cold in the Low Countries index are not or very badly covered by the Norfolk manorial accounts. To these belong 1290 and 1330, which are also marked as very wet in the precipitation index by Ogilvie and Farmer (1997) for England, so the likelihood that the cold conditions stretched from the continent over to England is high. The summer half year 1294 is very bad in the Low Countries index, once more Ogilvie records high rainfall levels and merely one Norfolk manorial account survives, pointing to cold growing season temperatures. Also the years of the Great Famine 1315-1317 (Lucas 1930; Kershaw 1973) are almost totally missing in the Norfolk data. Very few accounts are available for 1315/6 and none 1316/7. This lacuna in the Norfolk information during these crisis years, especially for the usually reliable prior's manors of Norwich Cathedral Priory, can lead to an underestimation of very cold growing seasons and their effects in the Norfolk growing season temperatures prior to 1350 .

On a decadal level the datasets (Fig. 7a) display some, though not a continuously strong, resemblance in trends before 1325, but the values are offset. During this period the Norfolk growing season temperatures are above average, while the Low Countries index fluctuates around the mean. Between 1325 and the early 1350s there is a very close match of the Dutch and Norfolk conditions. This also applies to the years 1395-1410. There remains a close relationship between the two datasets from c. 1355 to c. 1410 , excepting the 1380 s. After 1410 and particularly after 1420 the Low Countries index reflects warm summer seasons whereas reconstructed Norfolk growing season temperatures are low and display a weak downward trend. 

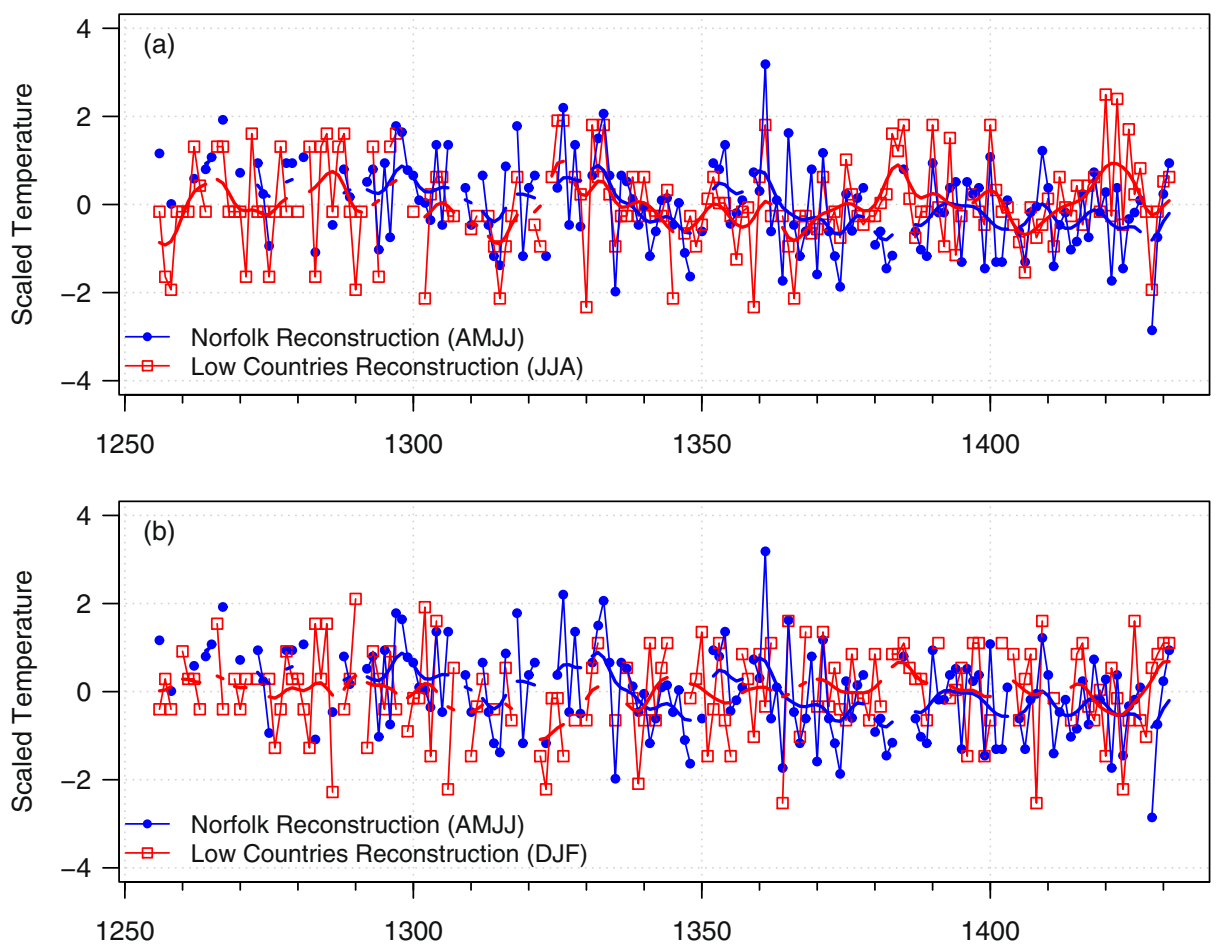

Fig. 7 A comparison of temperature series for the Low Countries (JJA and DJF) (van Engelen et al. 2001) and the reconstructed Norfolk temperature series (AMJJ)

Generally for two datasets derived from independent evidence for a time around 650 years ago and covering not exactly the same period of the year, coming not from the same region and one being a proxy reconstruction, the reconstructed Norfolk temperatures and the Low Countries summer index match astonishingly well. A difference emerges in respect to long-term trends. Whereas a long-term trend towards cooler conditions characterises the reconstructed Norfolk temperatures, such a tendency is not visible in the Low Countries data.

Closer attention shall be paid to the three periods where the trends of reconstructed Norfolk growing season temperatures and the Low Countries summer season index diverge c. 1355 -c. 1370 , c. $1380-1395$ and after 1420 . Since both data sets do not represent an identical period of the year, the reason for the break-up of their trends might not lie in their representation of the period of the year they have in common, May to July, but in the time before that: April and potentially March, which are not included in the Low Countries summer season index. Fortunately van Engelen et al. (2001) also constructed a winter season index (November to March) which gives 136 values between 1256 and 1431. A comparison between the reconstructed April-July temperatures and the Low Countries indices (Fig. 7) reveals that there are indeed occasions when the reconstructed Norfolk temperature shows a stronger connection to the Dutch winter conditions, than to the summer temperatures. Regarding warm and very warm Norfolk growing seasons on an annual level this is the case in, 1316, 1365 and 1409 (Fig. 7b). Cold and very cold Norfolk growing seasons which are not sufficiently mirrored in the Low Countries summer index, but 
show a link to the winter conditions are 1364, 1367, 1399, 1423 and 1424. In 1302 a very mild winter was followed by a very cold summer in the Low Countries and in 1420 the situation was reversed, in both years the Norfolk growing season temperature is average. The cause of this link between Dutch winter conditions and Norfolk growing season temperature is not the severity of the mid-winter period, but the length of the winters. Cold conditions in early spring delay the onset of the growing season in March and April, and therefore the harvest date; mild winters advance the growing season. Independent documentary evidence confirms long winters for 1363-1364 which was also exceptionally hard and continued into March (Ogilvie and Farmer 1997), and for 1422-1423 and 1423-1424 (the manorial accounts of estates of the Bishopric of Winchester in Titow (1970)).

The reconstructed warmer growing season conditions in Norfolk during the 1360s appear to be related to a period of milder winters in the Low Countries (apart from 1363-1364) which brought an early start of the growing season, although summers temperatures were merely average or below average. Central European winters were generally mild apart from 13631364 and the last years of the decade (Pfister et al. 1996). An explanation can be sought in an increase in westerlies throughout the year over northwest Europe. High rainfall levels in the summer half years of this decade (Ogilvie and Farmer 1997; Pribyl 2011) and partly also in the winter half years (Ogilvie and Farmer 1997) add substance to this hypothesis.

The case is different for the 1420s. Whereas single years of very warm Norfolk growing seasons linked to warm winters and thus early onsets of the growing season occur over the whole reconstruction period, very cold Norfolk growing seasons without an adequate reflection in the Low Countries summer index but a link to winter conditions are restricted to the latter half of the reconstruction period and cluster in the 1420s. At about 1420 the Dutch summer season and winter season index diverge. Summers get warmer, whereas winters cool slightly. This coincides with the break-up of the reconstructed Norfolk AprilJuly temperatures and the Low Countries summer season index. All this suggests that 1422-1423 and 1423-1424 are merely extreme examples in a decade of prolonged and potentially cold winters. Norfolk is vulnerable in respect to delayed growing seasons, because cold northerly and easterly winds in springtime hit the county unhindered. This applies above all to the land along the north coast and consequently also the manors of the Northwest group (MAFF 1972), which are the main source of harvest dates in the 1420s. It can be concluded that cool early springs delayed the growing season and harvest date in Norfolk. Summer temperatures could not recompense for this delay, and so the cool early spring is finally reflected in the reconstructed April-July temperatures. This pattern of delayed onsets of growing seasons or springs (a shift in seasonality) was typical for the LIA and such conditions prevailed during the 1420 s.

The reason for break-up in the relationship between reconstructed Norfolk temperatures and the Low Countries summer season index between c. 1380 and 1395 cannot be determined, Dutch winters were generally mild during this period. However, central European winters were mostly marked by average or cold conditions, merely two can be classified as mild during those years (Pfister et al. 1996). This might result in later springs. In England there is documentary evidence for late springs, but merely for the spring 1388 (Ogilvie and Farmer 1997). It is also possible that in some severely hot and dry summer seasons the development of the vegetation was delayed by drought.

In respect to the agricultural productivity and April-July mean temperature it has to be stated that the temperature is not the main factor for grain harvest yield, although it determines the grain harvest date. The long-term trend towards cooler growing season temperatures would have caused no major problems for farming apart from very cold and wet years, because the growing season in southern England is generally long enough for the 
grain crops. The situation is different for high levels of interannual variability, which would have made an adaptation to the prevailing weather conditions by the medieval farmer difficult. In England warm growing seasons, especially between late spring and midsummer, tend to be associated with dry conditions and cooler May-July periods with wetter conditions. The English medieval corn crops favour different growing conditions, and the impact of warm, cold, dry or wet spells depends on their timing. Importantly the phases of high interannual variability in growing season temperature 1315-1335 and 1360-1375 coincide with periods of high grain prices and partly even prolonged famine conditions. This can partly be attributed to abysmally cold and wet years also being contained in such phases, but it cannot be discounted that the vulnerability of medieval agriculture must have been increased by frequent shifts in weather patterns.

\section{Conclusion}

It has been shown in this paper that an annually-resolved temperature series for April to July mean temperatures 1256-1431 can be reconstructed from grain harvest dates using a linear regression transfer function. The regression was derived from eighteenth-nineteenth century harvest dates which overlap with the instrumental measurements of the CET. For a medieval temperature reconstruction based on documentary sources the series is remarkably complete. This has been made possible by the relative high survival rate of manorial accounts of Norwich Cathedral Priory and the supplementary series.

As with all analyses that use the transfer function technique the assumption has to be made that the relationship between April-July mean temperatures and harvest date in the calibration period also holds for the reconstruction period. To ensure that this requirement is met, as far as possible, calibration data were selected for a period before mechanisation could have an appreciable effect on the harvest date and thus on the results.

Of note is the decline of values over the 1256-1431 period which is apparent even when the errors associated with the individual values are taken into account. This would appear to be related to a deterioration of the climate towards the onset of the LIA. Since in the 1420s the reconstructed Norfolk growing season temperatures diverge substantially from the Low Countries summer half year index (van Engelen et al. 2001), it can be assumed that the cooling of the Norfolk April-July mean temperatures was due to a shift in seasonality: prolonged winters caused a delayed onset of the growing season.

Within this decline there is a high rate of interannual variability which on average is comparable with the instrumental series. That this is a real rate and not caused by the regression is clear when comparing the interannual variability of the raw medieval harvest dates with the eighteenth century dates. Any anthropogenic effect on the grain harvest date would rather result in a decrease in variance. However, the medieval data are marked by periods of alternating low and high variability. Periods of very high interannual variability are 1315-1335 and 1360-1375, periods of low interannual variability occurred in the second half of the $1330 \mathrm{~s}$ and in the $1340 \mathrm{~s}$, the $1350 \mathrm{~s}, 1390 \mathrm{~s}, 1410 \mathrm{~s}$ and potentially the years up to 1290 and in the late 1370 s and early 1380 s. In addition, decadal variability is evident with the April-July mean temperatures of the 1320 s to the early 1330 s and the 1360 s being warm and the late 1330 s, 1340 s as well as the 1380 s being cold.

Acknowledgements K. Pribyl was supported by the EU-project MILLENNIUM (contract no 017008-2) and the Swiss NCCR. We wish to thank Dirk Riemann (University of Freiburg) for his early work with the temperature reconstruction using the Norfolk harvest date series. The temperature indices made by van 
Engelen et al. (2001) for the Low Countries were obtained from http://www.knmi.nl/klimatology/ daggegevens/antieke_wrn/ and the Central England Temperature series was obtained from http:/hadobs. metoffice.com/hadcet/.

\section{References}

Aguilar E, Auer I, Brunet M, Peterson TC, Wieringa J (2003) Guidelines on climate metadata and homogenization, WCDMP-No. 53, WMO-TD No. 1186. Tech. rep., World Meteorological Organization, Geneva

Alexandre P (1987) Le climat au Moyen Age. Contribution à l'histoire des variations climatiques de 1000 à 1425 , d'après les sources narratives de l'Europe occidentale, Paris

Ault WO (1972) Open-field farming in medieval England. A study of village by-laws (Historical problems: Studies and documents, 16), London and New York

Brandon PF (1971) Late-medieval weather in Sussex and its agricultural significance. Trans Inst Br Geogr 54:1-17

Brázdil R, Kotyza O (1995) History of weather and climate in the Czech Lands I. Period 1000-1500 (Zürcher Geographische Schriften, 62), Zürich

Brázdil R, Kotyza O (2000) History of weather and climate in the Czech Lands IV. Utilisation of economic sources for the study of climate fluctuation at Louny and surroundings in the fifteenth-seventeenth centuries. Masaryk University, Brno

Brázdil R, Dobrovolný P, Luterbacher J et al (2010) European climate of the past 500 years: new challenges for historical climatology. Clim Chang 101:7-40. doi:10.1007/s10584-009-9783-z

Briffa KR, Jones PD, Pilcher JR, Hughes MK (1988) Reconstructing summer temperatures in Northern Fennoscandinavia back to A.D. 1700 using tree-ring data from Scots Pine. Arctic Alpine Res 20:385-394

Britton CE (1937) A meteorological chronology to AD 1450 (Meteorological Office Geophysical Memoirs, 70), London

Buisman J, van Engelen AFV (1995) Duizend Jaar Weer, Wind en Water in de Lage Landen, Franeker, vol. 1 (to 1300), vol. 2 (1300-1450) 1996, vol. 3 (1450-1575) 1998

Campbell BMS, Overton M (1993) A new perspective on medieval and early modern agriculture: six centuries of Norfolk farming c. 1250-c. 1850. Past and Present 141:38-105. doi:10.1093/past/141.1.38

Campbell BMS (2000) English seignorial agriculture 1250-1450. Cambridge University Press, Cambridge

Chuine I, Yiou P, Viovy N, Seguin B, Daux V, Le Roy Ladurie E (2004) Grape ripening as a past climate indicator. Nature 432:289-290. doi:10.1038/432289a

Collins EJT (1969) Harvest technology and labour supply in Britain, 1790-1870. Econ Hist Rev (new series) 22(3):453-473

Cook ER, Briffa KR, Jones PD (1994) Spatial regression methods in dendroclimatology: a review and comparison of two techniques. Int J Climatol 14:379-402

Ernle Lord (1961) English farming. Past and present. 6th edn., London, Melbourne and Toronto

Hallam HE (1984) The climate of eastern England 1250-1350. Agr Hist Rev 31:124-132

Hatcher J (1977) Plague, population and the English economy 1348-1530 (Studies in economic and social history), London and Basingstoke

Jones PD, Hulme M (1997) The changing temperature of "Central England”. In Hulme M, Barrow E (eds) Climates of the British Isles - present, past and future, London, pp 173-96

Jones PD, Briffa KR, Osborn TJ et al (2009) High-resolution palaeoclimatology of the last millennium: a review of current status and future prospects. Holocene 19/1:3-49. doi:10.1177/0959683608098952

Kershaw I (1973) The great famine and agrarian crisis in England, 1315-1322. Past and Present 59:3-50

Kiss A, Wilson R, Bariska I (2011) An experimental 392-year documentary- based multi-proxy (vine and grain) reconstruction for May-July temperatures for Közseg, West Hungary. Int J Biometeorol 55:595-611. doi:10.1007/s00484-010-0367-4

Lamb H (1977) Climate, present, past and future. vol. 2: Climate history and the future, London

Lucas HS (1930) The great European famine of 1315, 1316 and 1317. Speculum 5:343-377

MAFF (Ministry of Agriculture, Fisheries and Food) (1972) Agricultural land classification of England and Wales, sheet 124, King's Lynn

Manley G (1953) The mean temperature of central England, 1698-1952. Q J Roy Meteorol Soc 79:242-261

Manley G (1974) Central England temperatures: monthly means 1659-1973. Q J Roy Meteorol Soc 100:389-405

Mann M (2009) Global signatures and dynamical origins of the little ice age and the medieval climate anomaly. Science 326:1256-1260. doi:10.1126/science.1177303 
Možný M, Brázdil R, Dobrovolný P, Trnka M (2011) Cereal harvest dates in the Czech Republic between 1501 and 2008 as a proxy for March-June temperature reconstruction. Climatic Change, in press. doi: $10.1007 / \mathrm{s} 10584-011-0075-\mathrm{z}$

Nordli PØ (2001) Reconstruction of nineteenth Century summer temperatures in Norway by proxy data from farmer's diaries. Clim Chang 48:201-208. doi:10.1023/A:1005698302572

Nordli PØ (2003) Spring-summer temperature reconstruction in western Norway 1734-2003: a datasynthesis approach. Int J Climatol 23:1821-1841. doi:10.1002/joc.980

Ogilvie A, Farmer G (1997) Documenting the medieval climate. In: Hulme M, Barrow E (eds) Climates of the British Isles-present, past and future, London, pp 112-133

Pfister C, Luterbacher J, Wanner H et al (2008) Documentary evidence as climate proxies. Proxy-specific white paper produced from the PAGES/CLIVAR workshop, Triest, PAGES (Past global changes), Bern. Available at http://www.pages-igbp.org/cgi-bin/WebObjects/products.woa/wa/product?id=331

Pfister C, Schwarz-Zanetti G, Wegmann M (1996) Winter severity in Europe: the fourteenth century. Clim Chang 34:91-108

Pfister C (1979) Getreide-Erntebeginn und Frühsommertemperaturen im schweizerischen Mittelland seit dem 17. Jahrhundert. Geograph Helv 1:23-35

Pribyl K (2011) Weather in Late Medieval Norfolk. Agricultural practices and their climatological significance (unpub. Ph.D thesis, Univ. of Bern)

Soil Survey of England and Wales (1983) Soils of England and Wales. Sheet 4 Eastern England 1:250000, Rothamstead Experimental Station, Harpenden

Stern DV (1978) A Hertfordshire manor of Westminster Abbey: an examination of demesne profits, corn yields and weather evidence (unpub. Ph.D. thesis, Univ. of London, 1978). The thesis was published in 2000 by C. Thornton

Stone D (2005) Decision-making in medieval agriculture. Oxford University Press, Oxford

Tait J (1914) Chronica Johannis de Reading et Anonymi Cantuariensis 1346-1367, Manchester

Tarand A, Kuiv P (1994) The beginning of the rye harvest - a proxy indicator of summer climate in the Baltic area. Paleoclimatic Research 13 (Special issue ESF project "European paleoclimate and man" 8 1994), 61-72

Titow J (1960) Evidence of weather in the account rolls of the bishopric of Winchester 1209-1350. Econ Hist Rev (new series) 12:360-407

Titow J (1970) Le climat à travers les rôles de comptabilité de l'évêché de Winchester (1350-1450). Annales. Économies, Sociétés, Civilisations 25(2):312-350

van Engelen AFV, Buisman J, Ijnsen F (2001) A millennium of weather, winds and water in the Low Countries. In: Jones PD, Ogilvie AEJ, Davies TD, Briffa KR (eds) History and climate: memories of the future? New York et al, pp 101-24

Virgoe R (1996) The Estates of Norwich Cathedral Priory, 1101-1538. In: Atherton I, Fernie E, Harper-Bill C, Smith H (eds) Norwich Cathedral. Church, City, and Diocese, 1096-1996, 339-359, London, pp 339-59

Wade Martins S, Williamson T (1999) Roots of change. Farming and the landscape in East Anglia, c. 1700-1870 (The Agricultural History Review Supplement Series 2), Exeter

Wetter O, Pfister C (2011) Spring-summer temperatures reconstructed for northern Switzerland and south-western Germany from winter rye harvest dates, 1454-1970. Clim Past Discuss 7:2609-2654. doi:10.5194/cpd-7-2609-2011 